\title{
Defense Response in Slash Pine: Chitosan Treatment Alters the Abundance of Specific mRNAs
}

\author{
Mary E. Mason ${ }^{1}$ and John M. Davis ${ }^{2}$ \\ ${ }^{1}$ USDA Forest Service, Southern Institute of Forest Genetics, Harrison Experimental Forest, 23332 Hwy 67, \\ Saucier MS 39574 U.S.A.; ${ }^{2}$ School of Forest Resources and Conservation, and Plant Molecular and Cel- \\ Iular Biology Program, Box 110410, University of Florida, Gainesville FL 32611 U.S.A. \\ Received 9 September 1996. Accepted 19 September 1996.
}

\begin{abstract}
We used differential display to identify chitosan responsive cDNAs in slash pine cell cultures. Two clones that showed increased mRNA abundance had sequence similarity to genes with roles in major plant defense responses, clone 18 to cinnamic acid 4-hydroxylase, and clone 30 to chitinase.
\end{abstract}

Additional keywords: cytochrome P450, elicitation, Pinus elliottii.

Slash pine (Pinus elliottii var. elliottii Engelm.) is an ecologically and economically important species in the southern United States. Although genetic resistance to several pathogens has been inferred (Nelson et al. 1993), the underlying biochemistry of pine:pathogen interactions is poorly understood. Consequently, genes that condition disease resistance have not been identified in pines. Cell culture systems in conjunction with fungal cell wall elicitors have proven useful for inducing defense responses in pines and other gymnosperms (Campbell and Ellis 1992; Galliano et al. 1993; Lange et al. 1994; Lesney 1990; Popp et al., in press), and could facilitate identification and characterization of genes involved in a defense response in pines. Chitosan treated slash pine cultures showed browning of the culture medium, increased lignification, and increased activity of several enzymes including chitinase and glucanase (Lesney 1990; Popp 1993; Popp et al., in press).

The objective of the study reported here was to determine if the previously observed phenotypic changes in chitosantreated cell cultures are associated with changes in mRNA abundance. Differential display of mRNA (Liang and Pardee 1992) was selected because it allowed screening of a large number of transcripts simultaneously, the product of the mRNA need not be known, and it allowed simultaneous selection of transcripts whose abundance appeared to increase, decrease, or remain unchanged. We used a clonal cell line in

Corresponding author: M. E. Mason; E-mail: mason@datasync.com

Genbank accession numbers UU55005-14.

This article is in the public domain and not copyrightable. It may be freely reprinted with customary crediting of the source. The American Phytopathological Society, 1997. this study because pines are genetically heterogeneous due to high levels of outcrossing (Friedman and Adams 1985). The use of seedling material could create "false positives" due to allelic differences instead of expression differences.

Cell cultures of slash pine genotype \#52-56 were elicited for $24 \mathrm{~h}$ using chitosan $(60 \mu \mathrm{g} / \mathrm{ml}$ final concentration, Lesney 1990). Total RNA was isolated from elicited and untreated cells using the method of Schneiderbauer et al. (1991) and then used for differential display of mRNA (Liang and Pardee 1992) according to the methods of Liang et al. (1993) with minor modifications. We used total RNA as substrate for the reverse transcriptase reaction, and substituted $\left[\alpha^{33} \mathrm{P}\right] \mathrm{dATP}$ for $\left[\alpha^{35} \mathrm{~S}\right] \mathrm{dATP}$. The University of Florida's Interdisciplinary Center for Biotechnology Research (UF/ICBR) DNA Synthesis Core supplied primers (Table 1).

A total of 63 differential products (44 from elicited RNA and 19 from control RNA) were identified on polyacrylamide gels (Fig. 1), and 39 were selected for reamplification and cloning. Reamplified samples that showed ambiguous products were discarded. Twenty three products (14 from elicited RNA and 9 from control RNA) reamplified as expected.

Table 1. Primers used for differential display

\begin{tabular}{ll}
\hline Name & Sequence $\mathbf{5}^{\prime}$ to $\mathbf{3}^{\prime}$ \\
\hline Anchored primers & \\
71 & TTTTTTTTTTTTTTTAA \\
72 & TTTTTTTTTTTTTTAG \\
73 & TTTTTTTTTTTTTTAC \\
74 & TTTTTTTTTTTTTAT \\
75 & TTTTTTTTTTTTTTGA \\
76 & TTTTTTTTTTTTTTGG \\
77 & TTTTTTTTTTTTTTGC \\
78 & TTTTTTTTTTTTTTGT \\
79 & TTTTTTTTTTTTTTCA \\
80 & TTTTTTTTTTTTTTCG \\
81 & TTTTTTTTTTTTTTC \\
82 & TTTTTTTTTTTTTTTCT \\
Arbitrary primers & \\
83 & GTTGCGATCC \\
84 & CAAACGTCGG \\
85 & AGGTGACGCT \\
86 & GACCGCTTGT \\
87 & AGCCAGCGAA \\
JOD6 & GGTGCAAACG \\
JOD7 & CGCAGCCAAG \\
\hline
\end{tabular}


These products were cloned into pGEM-T (Promega). After ${ }^{32} \mathrm{P}$-labeling using a random primer labeling kit (BRL), they were used as probes on Northern blots (Sambrook et al. 1989). Hybridization and washing conditions were as previously described (Church and Gilbert 1984) except that the final wash was performed at $55^{\circ} \mathrm{C}$.

Cloned products fell into one of three classes, A to $\mathrm{C}$ (Fig. $2)$ : class A clones $(10 / 23 ; 43 \%)$ showed the expected pattern of expression on Northern blots; class B clones $(7 / 23 ; 30 \%)$ were derived from elicited or control RNA and were not changed by chitosan treatment (i.e., they were false positives); and class $C$ clones $(6 / 23 ; 26 \%)$ were uninterpretable due to lack of signal on the Northern blot autoradiographs. This class could be composed of low abundance mRNAs, A/T base rich clones that were removed by washing, or cloning artifacts.

Class $\mathrm{A}$ and $\mathrm{C}$ clones were sequenced at the UF/ICBR DNA Sequencing Core, and analyzed using the facilities of the UF/ICBR Biological Computing Core. Alignments and

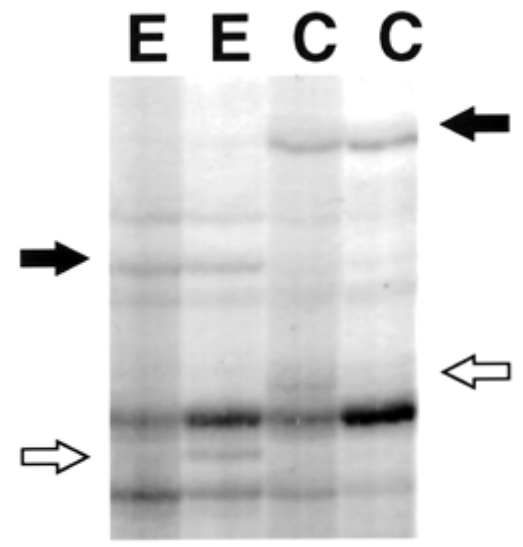

Fig. 1. A portion of a differential display autoradiograph showing the differences between lanes derived from elicited cell RNA and control cell RNA. Solid arrows identify products selected for further analysis, while hollow arrows identify nonreproducible products (not selected). Arrows to the left identify products unique to elicited cell RNA, and those to the right, products unique to control cell RNA. $\mathrm{E}=$ lane derived from elicited cell RNA, C = lane derived from control cell RNA. All lanes were amplified using the same primer pair. translations were conducted using GCG (Genetics Computer Group sequence analysis software, version 7.0 (Devereux et al. 1984), while searches were conducted using BLAST (Altschul et al. 1990). Ten clones that contained a poly-A tract and the expected 10-mer primer sequence have been submitted (Genbank accession numbers UU55005-14). Translated sequences of two submitted clones (clone 18 and clone 30) were similar to the $\mathrm{C}$-terminal regions of protein sequences in the database.

Clone 18 showed increased transcript abundance in elicited cells (Fig. 2), and the translated sequence showed 68\% identity to a cytochrome $\mathrm{P} 450$ enzyme, cinnamic acid 4hydroxylase $(\mathrm{C} 4 \mathrm{H})$ from sunflower (Fig. 3A; Teutsch et al. 1993, Bolwell et al 1994). C4H catalyzes the hydroxylation of trans-cinnamic acid to trans-p-coumaric acid in the phenyl-

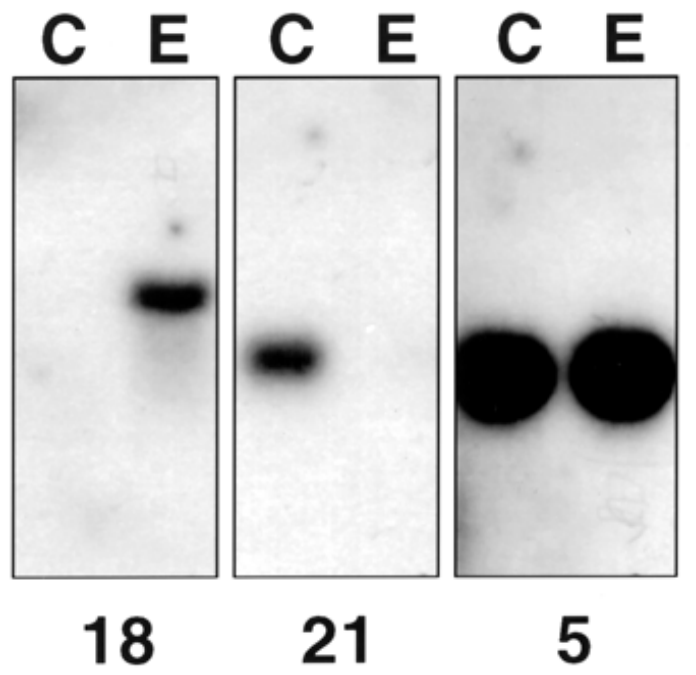

Fig. 2. Northern blots using differentially displayed products as probes. Left panel, class A clone selected from elicited lane showing the expected increase in transcript abundance in elicited cells. Center panel, class A clone selected from control lane showing the expected decrease in expression in elicited cells. Right panel, class B clone selected from elicited lane showing no change in transcript abundance, i.e., a false positive. $\mathrm{E}=$ elicited cell RNA, $\mathrm{C}=$ control cell RNA. The number below the panel is the number of the clone used as probe.

A

$\begin{array}{ll}\text { Ht } & \text { ITIGRLVQNFELLPPPGQSKIDTDEKGGQFSLHILKHSTIVAKPRSF } \\ \text { PC } & \text { IVIGRLVONFELLPPPGOSKIDTAEKGGQFSLOILKHSTIVCKPRSL } \\ 18 & \text { VTVGRLLONFELLPPPGKSKVDVSDKGGQFSLPILNHTLLVAKPRLPASS } \\ & -- \text {-GRL-ONFELLPPPG-SK-D---KGGQFSL-IL-H---V-KPR-- }\end{array}$

B

$\begin{array}{ll}\text { NtE } & \text { NDAVEDRIGYYRRYCGMLNVAPGENLDCYNQRNFGQG } \\ \text { NtV } & \text { DSRVODRIGFYRRYCSILGVSPGDNLDCGNORSFGNGLLVDTM } \\ 30 & \text { GDROOGRIGFYORYCSLLGVDTGSNLDCONOKHF } \\ & -----R I G-Y-R Y C--L-V-\text { - G-NLDC-NQ--F }\end{array}$

Fig. 3. A, Alignment of translated clone 18 with Ht (Helianthus tuberosus trans-cinnamate 4-monooxygenase; Teutsch et al. 1993) and Pc (Petroselinum crispum trans-cinnamate 4-monooxygenase; Logeman et al. 1995). B, Alignment of translated clone 30 with NtE (Nicotiana tabacum extracellular chitinase PR-Q; Payne et al. 1990) and NtV (Nicotiana tabacum vacuolar chitinase CHN50 (Shinshi et al. 1990). Residues conserved in all sequences are shown as capital letters in the bottom line. 
propanoid pathway (Dixon and Paiva 1995), several products of which may be associated with pine:fungal pathogen interactions. These compounds include lignin in pines (Rowan 1970) and pine cell cultures (Lesney 1989; Lesney 1990; Popp 1993, Popp et al., in press), stilbenes in infected tissues of pines (Jorgensen 1961) and pine cell cultures (Lange et al. 1994), and pigments, probably anthocyanins, at sites of presumed fungal interaction (Lundquist and Miller 1984; Miller et al. 1976).

Clone 30 (Fig. 3B, Payne et al. 1990; Shinshi et al. 1990) was induced by chitosan treatment (data not shown). Translated clone 30 showed $53 \%$ and $65 \%$ identity to extracellular and vacuolar chitinases, respectively, from tobacco (Fig. 3B). The translation product lacks the vacuolar targeting signal that is present in tobacco vacuolar chitinase (Neuhaus et al. 1991), suggesting the clone 30 gene product is an extracellular chitinase. Chitinases and other hydrolytic enzymes are recognized as pathogen-related proteins, and are induced during defense responses in many higher plants (Collinge et al. 1993; Stintzi et al. 1993). Secreted chitinase activity increased in loblolly pine cell cultures after chitosan treatment (Popp et al., in press), indicating chitinases are likely to be involved in pine:fungal interactions as well.

Differential display was used to clone elicitor responsive cDNAs in slash pine, demonstrating that changes in mRNA abundance are associated with elicitation in this species. Our results suggest that there are approximately as many transcripts induced by chitosan as suppressed, indicating elicitor treatment does not simply halt cellular function and kill the cells. We found that pine cells show a chitosan-induced increase in certain gene products associated with inducible defense responses in angiosperms. These clones can now be used as molecular probes to determine the extent to which these genes are involved in previously described defense responses in pines and other gymnosperms.

\section{ACKNOWLEDGMENTS}

We thank Susan D. Lawrence for helpful discussion of the work and manuscript and Robert L. Doudrick for helpful comments on the manuscript. We thank Greg Powell and Tim White (Cooperative Forest Genetics Research Program, University of Florida) for providing 52-56 branch material so we could initiate the cell cultures. This research was supported by the USDA Forest Service, Southern Institute of Forest Genetics through a Cooperative Research Agreement (19-94-068). This is Florida Agricultural Experiment Station Journal Series Article number R-05149. The use of trade names does not constitute endorsement by the USDA Forest Service.

\section{LITERATURE CITED}

Altschul, S. F., Gish, W., Miller, W., Myers, E. W., and Lipman, D. J. 1990. Basic local alignment search tool. J. Mol. Biol. 215:403-410.

Bolwell, G. P., Bozak, K., and Zimmerlin, A. 1994. Plant cytochrome P450. Phytochemistry 37:1491-1506.

Campbell, M. M., and Ellis, B. E. 1992. Fungal elicitor mediated responses of pine cell cultures: I. Induction of phenylpropanoid metabolism. Planta 186:409-417.

Collinge, D. B., Kragh, K. M., Mikkelsen, J. D., Nielsen, K. K., Rasmussen, U., and Vad, K. 1993. Plant chitinases. Plant J. 3:31-40.

Church, G. M., Gilbert, W. 1984. Genomic sequencing. Proc. Natl. Acad. Sci. USA 81:1991-1995.

Devereux, J., Haeberli, P., and Smithies, O. 1984. A comprehensive set of sequence analysis programs for the VAX. Nucleic Acids Res. 12:387-395.

Dixon, R. A., and Paiva, N. L. 1995. Stress-induced phenylpropanoid metabolism. Plant Cell 7:1085-1097.

Friedman, S. T., and Adams, W. T. 1985. Levels of outcrossing in two loblollly pine seed orchards. Silvae Genet. 34:4-5.

Galliano, J., Cabane, M., Eckerskorn, C., Lottspeich, F., Sandermann, H. Jr., and Ernst, D. 1993. Molecular cloning, sequence analysis and elicitor/ozone-induced accumulation of cinnamyl alcohol dehydrogenase from Norway Spruce (Picea abies L.). Plant Mol. Biol. 23:145156.

Jorgensen, E. 1961. The formation of pinosylvin and its monomethyl ether in the sapwood of Pinus resinosa Ait. Can. J. Bot. 39:17651772 .

Lange, B. M., Trost, M., Heller, W., Langebartels, C., and Sanderman, H. Jr. 1994. Elicitor-induced formation of free and cell-wall-bound stilbenes in cell-suspension cultures of Scots pine (Pinus sylvestris L.). Planta 194:143-148.

Lesney, M. S. 1989. Growth responses and lignin production in cell suspensions of Pinus elliottii 'elicited' by chitin, chitosan or mycelium of Cronartium quercuum f. sp. fusiforme. Plant Cell, Tissue, Organ Culture 19:23-31.

Lesney, M. S. 1990. Polycation-like behavior of chitosan on suspensioncultured derived protoplasts of slash pine. Phytochemistry 29:1123-1125.

Liang, P., Averboukh, L., and Pardee, A. B. 1993. Distribution and cloning of eukaryotic mRNAs by means of differential display: refinement and optimization. Nucleic Acids Res. 21:3269-3275.

Liang, P., and Pardee, A. B. 1992. Differential display of eukaryotic messenger RNA by means of the polymerase chain reaction. Science 257:967-971.

Logeman, E., Parniske, M., and Halbrock, K. 1995. Modes of expression and common structural features of the complete phenylalanine ammonia-lyase gene family in parsley. Proc. Natl. Acad. Sci. USA 92:5905-5909.

Lundquist, J. E., and Miller, T. 1984. Development of stem lesions on Slash pine seedling infected by Cronartium quercuum $\mathrm{f}$. sp. fusiforme. Phytopathology 74:514-518.

Miller, T., Cowling, E. B., Powers, H. R., and Blalock, T. E. 1976. Types of resistance and compatibility in slash pine infected by Cronartium fusiforme. Phytopathology 66:1229-1235.

Nelson, C. D., Doudrick, R. L., Nance, W. L., Hamaker, J. M., and Capo, B. 1993. Specificity of host:pathogen genetic interaction for fusiform rust disease on slash pine. In: Proceedings of the 22nd Southern Forest Tree Improvement Conference, June 14-17, Atlanta Ga.

Neuhaus, J-M., Sticher, L., Meins, F. Jr., and Boller, T. 1991. A short Cterminal sequence is necessary and sufficient for the targeting of chitinases to the plant vacuole. Proc. Natl. Acad. Sci. USA 88:10362-10366.

Payne, G., Ahl, P., Moyer, M., Harper, A., Beck, J., Meins, F. Jr., and Ryals, J. 1990. Isolation of complementary DNA clones encoding pathogenesis related proteins $\mathrm{P}$ and $\mathrm{Q}$, two acidic chitinases of tobacco. Proc. Natl. Acad. Sci. USA 87:98-102.

Popp, M. 1993. Induction of putative defense responses of slash and loblolly pines to bark beetle vectored fungi. Ph.D. dissertation, University of Florida.

Popp, M., Lesney, M. S., and Davis, J. M. Defense responses elicited in pine cell suspension cultures. Plant Cell, Tissue, and Organ Culture. In press.

Rowan, S. J. 1970. Fusiform rust gall formation and cellulose, lignin, and other wood constituents of loblolly pine. Phytopathology 60:1216-1220.

Sambrook, J., Fritsch, E. F., and Maniatis, J. 1989. Molecular Cloning: A Laboratory Manual. 2nd ed. Cold Spring Harbor Press, Cold Spring Harbor, NY.

Schneiderbauer, A., Sandermann, H. Jr., and Ernst, D. 1991. Isolation of functional RNA from plant tissues rich in phenolic compounds. Anal. Biochem. 197:991-995.

Shinshi, H., Neuhaus, J-M., Ryals, J., and Meins, F. Jr. 1990. Structure of a tobacco endochitinase gene: Evidence that different chitinase genes can arise by transposition of sequences encoding a cysteine-rich domain. Plant Mol. Biol. 14:357-368.

Stintzi, A., Heitz, T., Prasad, V., Wiedemann-Merdinoglu, S., Kauffman, S., Geoffroy, P., Legrand, M., and Fritig, B. 1993. Plant 'pathogenesis-related' proteins and their role in defense against pathogens. Biochimie 75:687-706.

Teutsch, H. G., Hasenfratz. M. P., Lesot, A., Stolz, C., Ganier, J. M., Jeltsch, J. M., Durst, F., and Werck-Reichhart, D. 1993. Isolation and sequence of a cDNA encoding a Jeruselum artichoke cinnamate 4hydroxylase, a major plant cytochrome P450 involved in general phenylpropanoid pathway. Proc. Natl. Acad. Sci. USA 90:4102-4106. 